\title{
Device-Related Infection
}

National Cancer Institute

\section{Source}

National Cancer Institute. Device-Related Infection. NCI Thesaurus. Code C78255.

An infectious disorder caused by the use of a medical device. 